\title{
撮影分科会教育講演
}

\section{Digital Angiography の臨床への適応と限界}

\author{
細 矢 貴 亮 \\ 山形大学医学部助教授
}

\section{はじめに}

CT p MRI のなかった時代，血管造影は最も優れた精 密画像診断法であった. 頭から足の先まで, 腫痬, 炎症, 血管障害，奇形に至るまで，血管造影なしでは診断でき ない疾患が数限りなく存在した．診断能の向上のために は血管造影における解像力とコントラストの向上が至上 命題であり，血管撮影機器の進歩の原動力となった。一 方，DSA (digital subtraction angiography) として実 用化されたデジタル血管撮影法は, 最近の技術革新によ り急速に普及してきた. また, MRI やCT の性能向上と 共に，血管撮影機器を使わないで血管像を得る方法も実 用段階に入ってきている. かつて，フィルム法でしか得 られなかった血管像が，様々な方法で得られる時代にな ってきたといえる．血管造影を頼まれたら，フィルムで 写してやれば良いという時代は終わっていると思う。

本稿では, 山形大学での経験を基に, まず血管造影以 外の方法で得られる MR angiographyについて簡単に 述べる. デジタル血管撮影については，その特徵を整理 するとともにフィルム撮影との関わりという観点から臨 床への適応を明らかにしたいと考えている。“デジタル血 管撮影の臨床への適応と限界”がお湾ろげながらでも見 えてくれれば幸いである。

\section{MR angiography}

最近の MRI は驚異的な進歩をとげ，血管撮影を行わ なくてもMR angiography (MRA)により動脈や静脈を 立体的に描出できるようになってきた. MRI が山形大学 に導入されたのは1991年のことであり，比較的新しい装 置である. 種々の撮像法で血管像を得ることができ，当 初臨床的な期待も大きかったが, 現在ではほとんど使用 していない. その大きな理由は, 次の 3 点にまとめるこ とができる.

1）撮像法の種類と臨床的有用性
一般に使われているMRA には, time of flight 法と phase contrast 法があり，それぞれ2D と3D を選択でき る.一長一短があるが, 総じて血管像に目的意識が乏し いと感じられる，技術の向上により確かに血管像は明膫 になってきているが，血管造影を行っている者の立場か ら考えると何の為の血管像なのか曖昧に思われるのであ る. 当施設では動脈溜のスクリーニングに MRI を使用 できるゆとりはなかったし，血管に異常が疑われる患者 の場合にもMRAが明らかに有用とは思われなかった。

\section{2) 技術的諸問題}

はじめに MRA を実施したときに感じたことは，あま りにも制約が多いことであった，導入した機種によると ころが大きかったのかもしれないが, MRI 装置の性能を 比較することは本来の目的ではないので割愛する.ここ では, どの機種にも共通して問題になると思われる解像 力についてとりあげてみたい.一般に，MRI の信号量は ボクセルの大きさに反比例する．解像力をあげようとす るとボクセルが小さくなり信号強度が不足する結果とな る. 当然, 解像力にも限界が生じる. 当施設での MRA は $256 \times 256$, スライス厚 $0.7 \mathrm{~mm}$ が最大の解像力を持つが, これではデジタル血管撮影における $1024 \times 1024$ マトリッ クスの解像力に遠くおよばない。

\section{3）原画像の有用性}

私どもは, MRI 導入当初より脳神経と血管を同時に描 出する方法を模索していた．MRA とは全く関係がなか つたが, 結果的に MRA の撮像法を改良して得られる原 画像が画質的にも時間的にも最も目的にかなうことがわ かった．血管が脳実質や腫湯と同時に観察できることで, 血管造影とは質の異なる情報を得ることができるように なり，種々の疾患で非常に高い臨床的評価を得ている (Fig. 1-3).

\section{デジタル血管撮影とは？}

“デジタル血管撮影”という言葉は，既に一般的に使用 
A

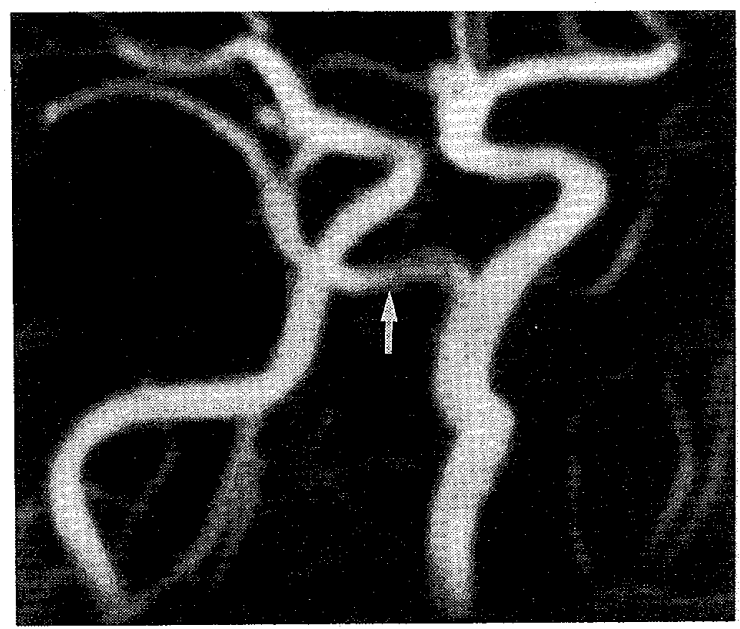

$\mathrm{B}$

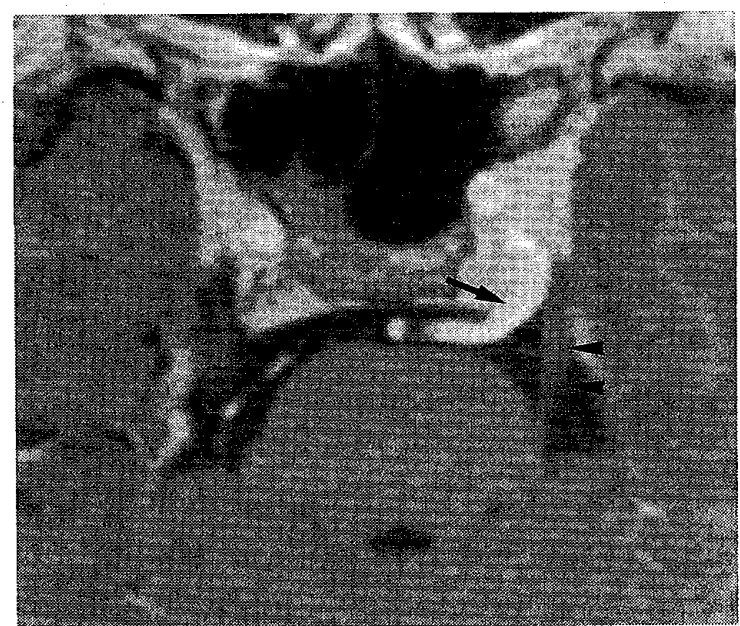

C

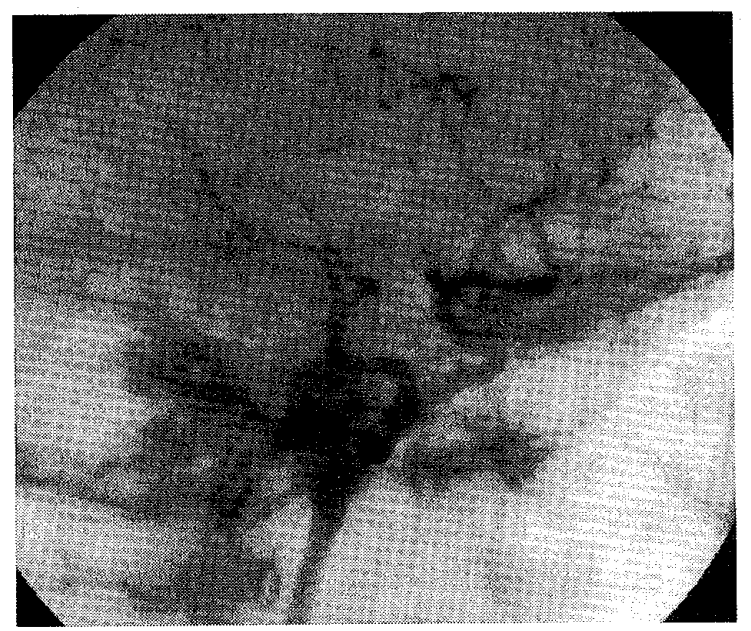

Fig. 1 Persistent primitive trigeminal artery

A : 3D phase contrast MRA の斜位像で, 左内 頸動脈と脳底動脈を結ぶ異常な動脈を認める $(\rightarrow)$. $\mathrm{B}: 3 \mathrm{D}$ time of flight MRA の原画像で, 問題の動 脈 ( $\rightarrow$ は は叉神経（一）に接して走行しているこ とがわかる，C：左内頸動脈の回転 DA で, 問題の 動脈を介して脳底動脈が造影された。
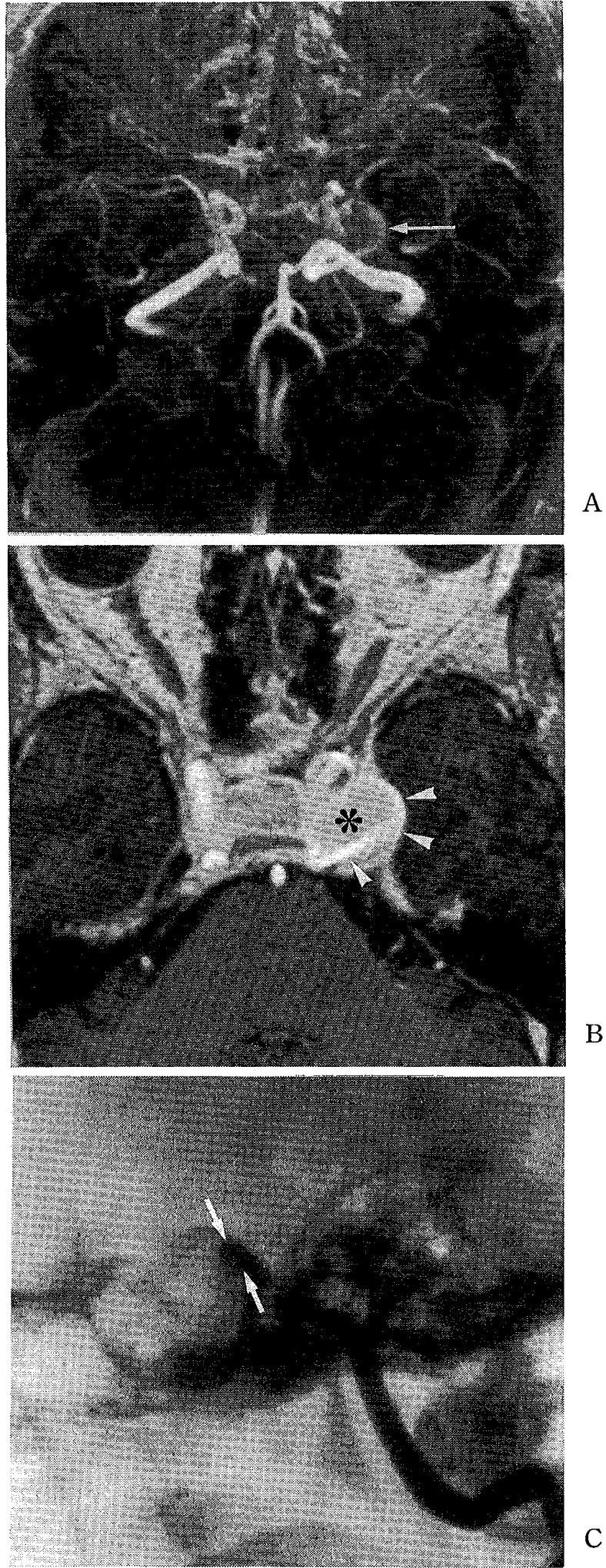

Fig. 2 内頸動脈の巨大動脈瘤

A : 3D time of flight MRA で, 左内頸動脈に動 脈瘤を認める $(\rightarrow)$ が, 不明暸である. B : 同原画 像では明暸な高信号を示すと同時に，内頸動脈(一) と動脈瘤（*）の関係もわかる. C : バルーンカテ ーテルを用いた左内頸動脈 DA 像により, 菱 $(\rightarrow)$ が比較的狭いことが確認できた。 


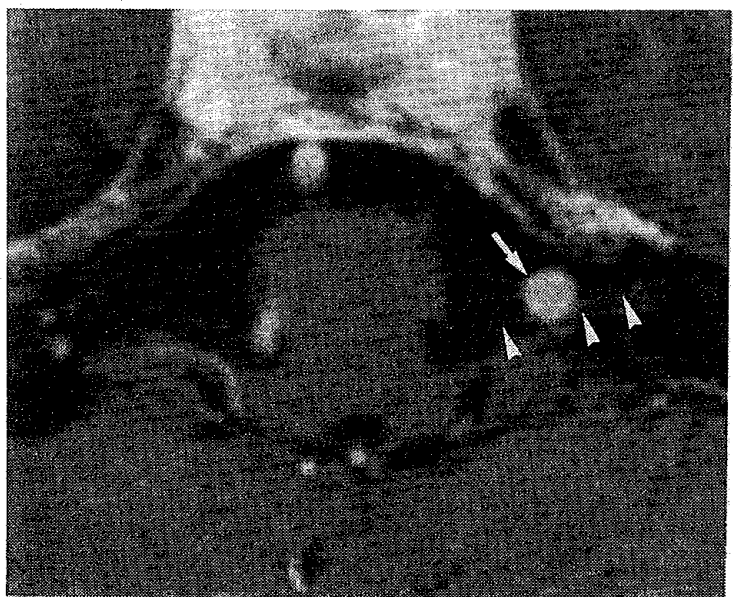

Fig. 3 前下小脳動脈の動脈溜

くも膜下出血で発症した患者に行った初回の血管 造影 (4 vessel) では, 明かな動脈瘤を指摘できなか った. 3D time of flight MRA の原画像で, 左前下 小脳動脈に連続し顔面神経 $($ 一) と接する動脈瘤 $(\rightarrow)$ が発見された。

されているように見受けられる。しかしながら，はじめ てこの言葉を使ったときにはかなりの勇気が必要であっ た. 当時の血管撮影はフィルム撮影とDSA であり,デジ タルの撮影はDSA そのものだったからである.サブト ラクションしていないデジタルの血管像は, 非サブトラ クションDSA などと表現されており, DSA の特殊撮影 にすぎなかった.

1988年に当施設に導入した血管撮影装置には，透視像 を記憶して必要に応じ再生するために，DSAに加え DVM (digital video memory) が付加されている. DVM は造影骫をテスト注入したときの像を再生できるように して，テスト注入を減らし血管造影の手技を行いやすく するために導入したのであるが，収集した透視像は十分 診断に役に立つことがわかった. DSA と違いサブトラク ションしていないので，C-アームを回転させたり，患者 を移動しながら撮影することができ，シネ撮影と同じ感 覚で診断に利用できるようになった。このような撮影法 はもともとサブトラクションを前提としていないので, DSA の特殊撮影として位置づけるのには抵抗があった. 当初は DVM 撮影という言葉を使う予定であったが，日 本語では理解できても英語にすると意味が通じなくなる と思われた. 良く考えると, 透視像をデジタル化してい るだけなのであるから,DSA におけるサブトラクション 前の画像を見ていることになる．動いていなければサブ トラクションすれば良いのだから，単にDA (digital angiography) と呼ぼうということになったのである.そ
して，DSA はDA システムの中に組み込まれるべきと 考えた。この考えは実現し, DSA もできるDA装置が既 に製品化されている.

ただ，DSA という言葉が既に一般化しており，DA と いう言葉では役不足の感じがした，DAを日本語に訳し ただけであるが，できるだけ“デジタル血管撮影”とい う言葉を使うようにしたのである.DSA を包含するよう なニュアンスがあるように思うのは著者だけであろうか.

\section{デジタル血管撮影は必要か？}

私どもがはじめて DSA を使用したのは1983年であっ た。当時の DSA には解像力を云々できるほどの性能は なく, 静注 DSA は現在の MRA に比べても見劣りのす る画像であった. 動注 DSA にしても, 腫瘍濃染を見るの に良いという評価はあったが, フィルム血管撮影が行わ れていることを前提としての話であった。フィルム血管 撮影に対抗するためには立体撮影が不可欠と考え，翌年 ステレオDSA を導入した。診断能は向上し臨床的評価 も高かったが，解像力に問題があり限られた症例を除け ばフィルム撮影を省略することはできなかった：そして， 最大の問題点は，ハレーション防止のための補償が面倒 で時間を要することであった．時間をかけ良い写真がで きると確かに診断的にも有用であったが, DSA がなけれ ば診断できなかったという症例は非常に少なかった. 当 時学会や雑誌では DSA は一つのトピックであったが, “血管撮影装置に DSA は絶対に必要ですか?”と聴かれ たとき，私は“予算があれば入れて下さい.十分遊べま す.予算がなければ必要ありません。診断能力は変わら ないと思います.”と答えていたのである。

ところが，現在の装置を使ったとたん，答えは $180^{\circ}$ 変 わってしまっていた：透視やDSA の解像力が向上した ばかりでなく，DVMによる新しい撮影法が臨床的に非 常に有用であったからである，1例をあげれば，従来時 間のかかっていた脊髄動脈撮影が，DAで行うようにな つて短時間で終了してしまうのである。便利さを知って しまうと，デジタル撮影がない装置で検查をすることが 苦痛となった。 “今度買うときは, 高くても DVM を入れ た方がいいですよ。これがないと先進医療に達れます。” 私は，半年前とは全く違うことを言っていた。

モニターで検査の手順を判断したり診断ができるよう になると, real time という利便性は絶対に捨てられな い. デジタル血管撮影装置は，今や必要不可欠と断言し て間違いないと思う。デジタル血管撮影を知らない人に は一度デジタル血管撮影装置を使ってみることをお搉め 
Table 1 デジタル血管撮影とフィルム血管撮影の 比較

\begin{tabular}{lccc}
\hline \hline \multicolumn{1}{c}{ 比較 項 目 } & デジタル & & フィルム \\
\hline 分解能 & & $<$ & \\
コントラスト & & $>$ & \\
コ動画 & & $>$ & \\
フィルム資源 & 少 & & 多 \\
保管 & 有利 & & 不利 \\
撮影労力 & & $?$ & \\
現場での診断 & 即時 & & 現像後 \\
塄影 & 楽 & & 手間 \\
被曝線量 & & $?$ & \\
\hline
\end{tabular}

する。

\section{デジタル血管撮影とフィルム血管撮影}

両者の長所と短所を表にまとめてみた（Table 1)。こ の表を見て多くの人は，デジタル血管撮影は解像力でま だフィルム血管撮影に劣っていると思われるだろう。し かし, 見方を変えればフィルム撮影が勝っているのは解 像力だけなのである。この点を記憶にとどめておいて欲 しいと思う。

撮影労力は, フィルム血管撮影では撮影中の肉体労働 が多く, デジタル血管撮影では撮影後の処理に時間がか かる．好みもあろうが，㴗同等というところと思う。 被曝線量については, デジタル血管撮影で多くなる傾问 があるが，適切な対策を講じればやはり同等と思われる。

\section{フィルム血管撮影は生き残れるか？}

最近，デジタル血管撮影はフィルム血管撮影に代わり えるか？という議論がある，誠にもっともなテーマで はあるが, 両者にはそれぞれに長所, 短所があり, 決着 はつけがたい. 答えの得られない議論になることは必定 である. 先に，デジタル血管撮影は絶対に必要であるこ とを述べたので，今度はフィルム血管撮影の必要性につ いて考えてみたい。おのずと，フィルム血管撮影が生き 残れるかどうかわかると思う。

まず，一例として脳血管撮影を取り上げて血管撮影の 適応を整理してみよう（Table 2)。この中で，フィルム 撮影の解像力を必要とする疾患はいくつあるだろうか? 現在では, 超音波, CT, MRI など他の画像診断法も発達 し，血管撮影そのものが不要になった疾患がある。デジ タル血管撮影の解像力で十分診断できる疾患も多い.フ
Table 2 脳血管造影の適応

\begin{tabular}{c}
\hline - 絶対的適応 \\
血管性病変 \\
動脈瘤 \\
動静脈奇形 \\
- 相対的適応 \\
血管性病変 \\
閉塞性血管障害 \\
原因不明の脳出血 \\
臐陽性病変 \\
- 研究的適応 \\
- 教育的適応
\end{tabular}

イルム血管撮影ではじめて診断できる疾患もあるが，そ の診断能には限界がある。最終的に組織診を必要とする ならば，フィルム血管撮影の臨床的貢献度は著しく低い という見方ができるかもしれない.フィルム撮影に固執 する人は, 日本で時速 $260 \mathrm{~km}$ だせる車を買う人に似て いると言ったら，言い過ぎであろうか？とは言っても， フィルム血管撮影は簡単にはなくならないであろう。私 には，フィルム血管撮影が胃透視と同じような道をたど るような気がしてならない. スピード狂がいるのと同じ ように, あくなき解像力の向上を目指寸臨床医や研究者 の数も少なくないのであるから……

\section{おわりに}

現在ではいろいろな画像診断技術が発達しており, 臨 床の場で適切な画像診断法を選択することが重要になっ ている. 血管撮影の役割も変化しつつあり，検査を行う 者は血管撮影の目的を十分認識する必要がある．当然の ことながら, 適切な画像診断法は, 各施設における画像 診断装置の質や臨床各科の要望により異なってくる. 実 状に合わせて検查を組み立てていくべきであろう。

デジタル血管撮影の各論については詳しく述べること ができなかったので，シンポジウムの内容を参照してい ただきたい. 本稿ではデジタル血管撮影の利点ばかり強 調してしまった感があるが，著者も完全にフィルムレス で良いとは考光ていない．実際に，フィルムでないと診 断できないかもしれない疾患について，現在研究中であ ることをつけ加えておく。

\section{参考文献}

1）細矢貴亮, 佐藤奈美, 山口昂一・他：MRIによる脳 
神経と血管の描出法 -3D-SPGR 法を用いて一。

日磁医誌，12，245-252，1992。

2）朝比奈宏, 大江光雄, 安原 弘・他：ディジタル・ ビデオ・メモリ装置の開発. 第44回日本医学放射線 学会総会学術研究発表抄録集. p. 948， 1988.

3）細矢貴亮，高梨俊保，山口昂一-他：高精細 TV と Digital Video Memory を備えた血管撮影装置の有 用性.メディカルレビュー，No. 33：9-18，1989.

4）細矢貴亮，山口昂一，内村文昭·他：DSA はフィル ム血管撮影に代わりうるか？A. 頭部。画像診断, 10, 1186-1192, 1990.

5）細矢貴宽，山口昂一：Digital radiography 3 デジタ ル血管撮影の臨床 一DVM を用いた新しい血管撮 影法。医学のあゆみ157：581-585，1991.
6) Sugai Y., Hosoya T., Yamaguchi K., Kaga Y.: Digital angiography using hand-operated table movement for vascular disease of the pelvis and lower extrimities. Radiation Medicine 10: 82-86, 1992.

7）細矢貴亮, 菅井幸雄, 山口昂一：〔特集〕インターベ ンショナルラジオロジー一手法の浸透《デジタル血 管撮影の発展と将来. 新医療 No. 214, 98-101, 1992.

8）細矢貴亮，高梨俊保，山口昂一・他：高精細 TV と Digital Video Memory を備えた血管撮影装置にお ける被曝線量について。映像情報21：523-527, 1989 . 